\title{
The novel model peptide, $\alpha$ AL14, regulates angiogenesis by inhibiting VEGFR 2-mediated signaling in HUVECs
}

\author{
NAN-HEE KIM ${ }^{1}$, CHANG-WON KANG ${ }^{1}$, HYE-JIN GO ${ }^{2}$, \\ CHAN-HEE KIM ${ }^{2}$, NAM GYU PARK ${ }^{2}$ and GUN-DO KIM ${ }^{1}$ \\ ${ }^{1}$ Department of Microbiology, College of Natural Sciences, and ${ }^{2}$ Department of Biotechnology, \\ College of Fisheries Sciences, Pukyong National University, Nam-gu, Busan 48513, Republic of Korea
}

Received May 10, 2016; Accepted July 7, 2016

DOI: 10.3892/ijo.2016.3651

\begin{abstract}
Inhibition of angiogenesis has been focused on as a strategy for treating several diseases including cancer. In this study, a novel model peptide $\alpha$ AL14 was synthesized and used to identify its inhibitory effects on angiogenesis. The anti-angiogenic effects of $\alpha$ AL14 were investigated using vascular endothelial cells, HUVECs. $\alpha$ AL14 inhibited critical angiogenic processes including tubule formation, cell migration and cell invasion with no influence on cell proliferation in HUVECs. Activity of VEGFR2 was inhibited by $\alpha$ AL14 treatment in HUVECs. Additionally, activities of major subsequent downstream factors of VEGFR2 such as ERK, FAK and Akt were decreased. $\alpha$ AL14 affected expression of Rac1, Cdc42, Arp2 and WAVE2 which are involved in formation of lamellipodia. Moreover, $\alpha$ AL14 reduced NF- $\kappa$ B that can promote expression of several genes relating to cell invasion such as MMP2 and MMP9. Therefore, the results suggest that $\alpha$ AL14 has a potential to be developed as anti-angiogenic drug for treating diseases driven by abnormal angiogenesis.
\end{abstract}

Correspondence to: Professor Nam Gyu Park, Department of Biotechnology, College of Fisheries Sciences, Pukyong National University, 45 Yongso-ro, Nam-gu, Busan 48513, Republic of Korea E-mail: ngpark@pknu.ac.kr

Professor Gun-do Kim, Department of Microbiology, College of Natural Sciences, Pukyong National University, 45 Yongso-ro, Nam-gu, Busan 48513, Republic of Korea

E-mail: gundokim@pknu.ac.kr

Abbreviations: HUVECs, human umbilical vein endothelial cells; VEGFR2, vascular endothelial growth factor receptor 2; VEGF, vascular endothelial growth factor; MAPK, mitogen-activated protein kinase; ERK, extracellular signal-regulated kinases; PI3K, phosphoinositide 3-kinase; FAK, focal adhesion kinase; MMPs, matrix metalloproteinases; NF- $\mathrm{B}$, nuclear factor- $\mathrm{\kappa B}$; ECM, extracellular matrix

Key words: $\alpha \mathrm{AL} 14$, anti-angiogenesis, vascular endothelial growth factor receptor 2, cell migration, cell invasion

\section{Introduction}

Angiogenesis, making new blood vessels from existing ones, is considered as a key process in many physiological and pathological states. Many reports have demonstrated that angiogenesis is strongly implicated on cancer progression and metastasis $(1,2)$. Research on the molecular mechanisms of angiogenesis has rapidly advanced and it has contributed to the approval of anti-angiogenic drugs for cancer (3). Recently, a large number of candidates composed of peptides have been developed because peptides have been considered as secure pharmaceutical reagents against angiogenesis-related diseases. However, there are many obstacles to synthesize optimized peptides for cancer treatment $(4,5)$.

Raddum et al revealed that seven different model peptides based on Annexin A2 (AnxA2) present anti-angiogenic effects on HUVECs. Especially, a synthetic peptide D1-P2 adopting higher $\alpha$-helical structure significantly inhibited network formation rather than the others in the co-culture system of HUVECs and SMCs (6). Therefore, in this study, in order to reveal whether peptides containing $\alpha$-helical structure can affect angiogenesis, a novel cationic linear $\alpha$-helical model peptide, $\alpha$ AL14, was used.

Therapeutic strategies for treating diseases with abnormal angiogenesis use control of VEGF receptor 2 because it can modulate main angiogenic processes such as endothelial cell proliferation, migration and tube formation by activating cellular key kinases, ERK, FAK and AKT $(7,8)$.

Rho GTPase family members are involved in cell migration. Best-studied Rho GTPases, Rac1, Cdc42 and RhoA, contribute to extend cell protrusions at the end of cell edge, motivating cells to migrate. Formation of lamellipodia is the primary step of cell migration. During cell migration, Rac1 activates Arp2/3 complex and WAVE2 to polymerize cytoskeletal sheets at the front of cells $(9,10)$. Like cell migration, cell invasion is triggered through degradation of ECM, secreting special proteolytic enzymes, MMPs. MMP2 and MMP9 have vital roles in the degradation of ECM during angiogenesis (11-13).

In this study, a novel $\alpha$-helical model peptide $\alpha$ AL14 was used to identify its anti-angiogenic properties. aAL14 inhibited angiogenesis by regulating VEGFR2-mediated signaling and it affected expression of Rho GTPases (Rac1 and Cdc42) 
and MMPs. Therefore, we can expect that this peptide can be applied for development of therapeutic peptides to treat angiogenesis-associated diseases such as cancer.

\section{Materials and methods}

Reagents. Matrigel was purchased from BD Bioscience (Bedford, MA, USA). Vascular endothelial growth factor (VEGF) was from Sigma-Aldrich (St. Louis, MO, USA). Formaldehyde (Junsei Chemical Co., Ltd., Tokyo, Japan), Giemsa (Gurr-Giemsa, BDH Merk Ltd., Poole, UK) and BrdU cell proliferation assay kit (Cell Signaling Technology, Danvers, MA, USA) were used. EGM-2 bullet kit was obtained from Lonza (Walkersville, MD, USA). Dulbecco's modified Eagle's medium (DMEM), fetal bovine serum (FBS) and antibiotics (penicillin and streptomycin) were obtained from Corning (Manassas, VA, USA). Hoechst 33342 and all of rabbit primary antibodies for western blot analysis, VEGF receptor 2 (1:1,000, \#9698), phospho-VEGF receptor 2 (Tyr1175) (1:1,000, \#2478), phospho-MEK1/2 (Ser217/221) (1:1,000, \#9154), phosphoERK1/2 (Thr202/Tyr204) (1:1,000, \#4370), RhoA (1:1,000, \#2117), Cdc42 (1:1,000, \#2466), Rac1 (1:1,000, \#2465), FAK (1:1,000, \#3285), phospho-FAK (Tyr397) (1:1,000, \#8556), phospho-FAK (Tyr576/577) (1:1,000, \#3281), phospho-FAK (Tyr925) (1:1,000, \#3284), phospho-Src (Tyr416) (1:1,000, \#6943), MMP2 (1:1,000, \#4022), MMP9 (1:1,000,\#3852), NF- $\kappa B$, phospho-NF- $\mathrm{B}$ (Ser536) (1:1,000, \#3033), Akt (1:1000,\#4691), phospho-Akt (Ser473) (1:1000,\#4060), mTOR (1:1000, \#2983), phospho-mTOR (Ser2481) (1:1000, \#2974), GAPDH $(1: 1,000$, \#2118) and $\beta$-actin $(1: 1,000, \# 4970))$ were purchased from Cell Signaling Technology Inc. and ERK2 $(1: 1,000, \mathrm{sc}-81457)$ for western blot analysis was purchased from Santa Cruz Biotechnology Inc. (Dallas, TX, USA). Secondary antibodies (horseradish peroxidase-conjugated anti-rabbit IgG second antibodies and anti-mouse IgG second antibodies) were purchased from Cell Signaling Technology Inc. Annexin V, Alexa Fluor ${ }^{\circledR} 488$ Conjugate, live cell imaging solution (1X) and ProLong ${ }^{\circledR}$ Gold Antifade mounting medium were purchased from Life Technologies (Carlsbad, CA, USA).

Peptide synthesis and structure prediction. $\alpha \mathrm{AL} 14$ was synthesized and purified as described (14). Briefly, $\alpha$ AL14 was commercially synthesized by Peptron Inc. (Daejeon, Korea) at a purity grade of $>95 \%$ using N-(9-fluorenylmethoxycarbonyl) (Fmoc) solid phase peptide synthesis with ASP48S. This peptide was purified by reverse phase high performance liquid chromatography (HPLC). Synthetic peptide was dissolved in sterilized distilled water to obtain stock solutions of $10 \mathrm{mg} / \mathrm{ml}$. The structure of $\alpha \mathrm{AL} 14$ was predicted as described previously (14). A theoretical isoelectric point (pI) of peptide was estimated using ExPASy's ProtParam server (http:// www.expasy.org) and helical wheel diagram was created by EMBOSS pepwheel sequence analysis program (European Bioinformatics Institute, Cambridge, UK) (15).

Cell culture. Human vascular endothelial cells (HUVECs) were purchased from American Type Culture Collection (ATCC, Manassas, VA, USA) and incubated with an endothelial basal medium-2 (EBM-2) including EGM-2 singleQuots kit, $1 \%(\mathrm{v} / \mathrm{v})$ penicillin-streptomycin and $10 \%(\mathrm{v} / \mathrm{v})$ FBS
Human keratinocytes (HaCat) and human embryonic kidney cells (HEK-293) were obtained from Korean Cell Line Bank (KCLB, Seoul, Korea). These two cell lines were incubated in Dulbecco's modified Eagle's medium (DMEM) supplemented with $1 \%(\mathrm{v} / \mathrm{v})$ penicillin-streptomycin and $10 \%(\mathrm{v} / \mathrm{v})$ FBS. The cells were maintained at $37^{\circ} \mathrm{C}$ and $5 \% \mathrm{CO}_{2}$ in a humidified atmosphere.

BrdU cell proliferation assay. Effects of $\alpha \mathrm{AL} 14$ on cell proliferation were investigated using BrdU cell proliferation assay kit. The BrdU assay was conducted according to the manufacturer's instructions. Cells $\left(1 \times 10^{4}\right.$ cells/well) were plated on a 96-well cell culture plate and treated with $\alpha$ AL14 $(0-40 \mu \mathrm{M})$ for $24 \mathrm{~h}$. After incubation, cells were incubated with BrdU for $4 \mathrm{~h}$ at $37^{\circ} \mathrm{C}$. BrdU incorporation was measured by microplate reader at $450 \mathrm{~nm}$. This assay was repeated three times.

Cell adhesion assay. Cell adhesion assay was performed as described previously, with some modifications (16). The 96-well cell culture plates were coated with $50 \mu \mathrm{g} / \mathrm{ml}$ Matrigel and left to air dry for $1 \mathrm{~h}$. Wells were blocked with $1 \%$ BSA for $1 \mathrm{~h}$ at room temperature and rinsed twice with $0.1 \%$ PBS before plating cells. HUVECs were suspended with complete EBM-2 media, and then seeded at $3.5 \times 10^{4}$ cells in each well, and then treated with various concentrations of $\alpha$ AL14 for $2 \mathrm{~h}$ at $37^{\circ} \mathrm{C}$. Cells were washed twice with $0.1 \%$ PBS. The cells attached on a bottom were fixed with $4 \%$ formaldehyde for $15 \mathrm{~min}$ and stained with $5 \mathrm{mg} / \mathrm{ml}$ crystal violet for $10 \mathrm{~min}$ at room temperature. Adhesive cells were observed with phase-inverted microscope and quantitated by dye extraction with $2 \%$ SDS. The absorbance was measured at $590 \mathrm{~nm}$. Experiments were performed in triplicates.

Transwell migration/invasion assay. Cell migration and invasion assay were performed as previously described, with some slight modifications (17). Briefly, Transwells with $8-\mu \mathrm{m}$ pore size membrane (Corning, Tewksbury, MA, USA) were used to examine cell migration and invasion of HUVECs. The lower chambers were filled with EBM-2 pure medium including $20 \mathrm{ng} / \mathrm{ml}$ VEGF. HUVECs (3.5x $10^{4}$ cells/insert) suspended in EBM-2 pure medium were added on each Transwell. The Transwells and lower chambers contained $\alpha$ AL14 $(0-20 \mu \mathrm{M})$. Migrated cells were measured after $24 \mathrm{~h}$ of incubation. Cells on topside of the membrane were removed by wiping with a cotton swab, then, the membrane was washed with 1X PBS. Cells on bottom side of the membrane were fixed with $4 \%$ formaldehyde for $15 \mathrm{~min}$, and stained with $5 \mathrm{mg} / \mathrm{ml}$ crystal violet for $10 \mathrm{~min}$ at room temperature. Images were taken using phase-inverted microscope at a magnification of $x 40$. To quantify migrated cells, 2\% SDS was added to lysis of the cells for $1 \mathrm{~h}$ at room temperature and an absorbance was measured at $590 \mathrm{~nm}$. To perform invasion assay, Transwells were coated with $30 \%$ Matrigel in pure EBM-2 medium and incubated for $3 \mathrm{~h}$ before adding cells on the inserts. Following procedure of this assay is the same with the migration assay using Transwells as above. Experiments were performed in triplicates.

Tube formation assay. The effect of $\alpha$ AL14 on tube formation was investigated in accordance with the procedure described by Kim et al (16). The 96-well cell culture plates were coated 
with $60 \mu \mathrm{l}$ of Matrigel per well, which was allowed to solidify at $37^{\circ} \mathrm{C}$ for $30 \mathrm{~min}$. HUVECs were seeded at a density of $2 \times 10^{4}$ cells per well on the Matrigel and incubated with complete EBM-2 medium containing different concentrations of $\alpha \mathrm{AL} 14(0-20 \mu \mathrm{M})$. After $18 \mathrm{~h}$, tubule structures were observed using a phase-inverted microscope. Quantification of total tube length was analyzed using Wimasis image analysis service, WimTube (Wimasis GmbH, Munich, Germany). Experiments were performed in triplicates.

Immunofluorescence staining and localization of peptide. Immunofluorescence staining was performed as described previously with some modifications (18). Briefly, HUVECs seeded on glass coverslips were treated with $15 \mu \mathrm{M} \alpha \mathrm{AL} 14$ for $30 \mathrm{~min}$, fixed with $4 \%$ formaldehyde for $15 \mathrm{~min}$ at room temperature, and blocked with $2 \% \mathrm{BSA}$ in PBS with $0.3 \%$ Triton X-100. These cells were then incubated with specific rabbit primary antibodies at $4^{\circ} \mathrm{C}$. Phospho-VEGF receptor 2 (Tyr1175) (1:100, \#2478), phospho-ERK1/2 (Thr202/Tyr204) (1:200, \#4370), phospho-Akt (Ser473) (1:200, \#4060) and Rac1 (1:25, \#2467) were purchased from Cell Signaling Technology, Inc. and phospho-FAK (Tyr397) (1:100, sc-11765) was purchased from Santa Cruz Biotechnology, Inc. The cells were incubated with $0.1 \mu \mathrm{g} / \mathrm{ml}$ of anti-rabbit $\operatorname{IgG}(\mathrm{H}+\mathrm{L}), \mathrm{F}\left(\mathrm{ab}^{\prime}\right) 2$ fragment (Alexa Fluor 488 conjugate) for $1 \mathrm{~h}$ at room temperature. Cells were stained with DAPI for $20 \mathrm{~min}$ at $37^{\circ} \mathrm{C}$. The cells were mounted using ProLong Gold Antifade mounting medium. Immunofluorescence was observed and imaged using a laser scanning confocal microscope (Carl Zeiss LSM 700; Carl Zeiss, Jena, Germany). To detect localization of $\alpha$ AL14, HUVECs were seeded on glass coverslips for $24 \mathrm{~h}$. After incubation, cells were treated with FITC-tagged $\alpha$ AL14 for the indicated time period. Cells were washed with live cell imaging buffer and stained with Hoechst 33342 for 10 min at $37^{\circ} \mathrm{C}$. After mounting, the localization of peptide in HUVECs was observed using a laser scanning confocal microscope.

Annexin V-FITC detection. To detect early apoptosis in aAL14treated HUVECs, Annexin V-FITC detection was performed according to the manufacturer's instructions. Briefly, HUVECs were seeded on glass coverslips and treated with $\alpha$ AL14 for $24 \mathrm{~h}$. After incubation, cells were washed with cold 1X PBS and incubated with Hoechst 33342 and Annexin V conjugate for $15 \mathrm{~min}$ at room temperature. After mounting, Annexin-Vpositive cells were observed using a laser scanning confocal microscope.

Western blot analysis. Western blot analysis was performed as previously described with some modifications (18). Briefly, after treatments, HUVECs were washed once with cold $1 \mathrm{X}$ PBS and then lysed with lysis buffer containing $50 \mathrm{mM}$ Tris- $\mathrm{Cl}$, pH 7.5, $150 \mathrm{mM} \mathrm{NaCl}, 1 \mathrm{mM}$ DTT, $0.5 \% \mathrm{NP}-40$, $1 \%$ Triton $\mathrm{X}-100,1 \%$ deoxycholate, $0.1 \%$ SDS and proteinase inhibitors (PMSF, EDTA, Aprotinin, Leupeptin, Prostatin A) (Intron Biotechnology, Gyeonggi, Korea). After $30 \mathrm{~min}$ on ice, lysates were centrifuged at $14,000 \mathrm{rpm}$ for $20 \mathrm{~min}$ at $4^{\circ} \mathrm{C}$ to remove cell debris and collect proteins. Proteins were separated by $12 \%$ SDS-polyacrylamide gel electrophoresis. The proteins were transferred to nitrocellulose membrane. The membranes were blocked with 5\% skim milk in 1X PBST. After blocking, the proteins were treated with primary antibodies $(1: 1,000)$ overnight at $4^{\circ} \mathrm{C}$. The proteins were incubated with horseradish peroxidase-conjugated anti-rabbit $\operatorname{IgG}$ second antibodies $(1: 2,000)$ or anti-mouse IgG second antibodies $(1: 2,000)$ for $1 \mathrm{~h}$ at room temperature. The membranes were then washed in 1X PBST and then developed by enhanced chemiluminescence ECL ${ }^{\circledR}$ (AbFontier, Gyeonggi, Korea). Band intensities were quantified using ImageJ.

Reverse transcriptase PCR. Total RNA from HUVECs $\left(1.0 \times 10^{7}\right.$ cells) was extracted using RNeasy Mini kit (Qiagen, Venlo, KJ, The Netherlands) according to the manufacturer's protocol and quantified by Qubit (Life Technologies). RNA $(1 \mu \mathrm{g})$ template in $20 \mu \mathrm{l}$ reaction volume was converted into a cDNA using AccuPower ${ }^{\circledR}$ RT PreMix from Bioneer (Daejeon, Korea). cDNA $(2 \mu \mathrm{l})$ was amplified in $20 \mu \mathrm{l}$ reaction volume for 25 cycles. Primers for human MMP2 (forward, 5'-TTGAC GGTAAGGACGGACTC-3' and reverse, 5'-ACTTGCAGTA CT CCCCATCG-3'), human MMP9 (forward, 5'-TTGACAGC GACAAGAAGTGG-3' and reverse, 5'-CCCTCAGTGAAGC GGTACAT-3') and human GAPDH (forward, 5'-CGGGAAA CTGTGGCGTGAT-3' and reverse, 5'-AGTGGGTGT CGCTG TTGAAGT-3'), were used. PCR product (5 $\mu \mathrm{l})$ was run in $2 \%$ agarose gel and stained with ethidium bromide solution and band intensities were quantified using ImageJ.

Statistical analysis. The prism 6.0 software (Graphpad, CA, USA) for window was used to confirm the statistical significance of differences between values for various experimental and control groups. Determinations were performed in triplicate and results are expressed as mean \pm standard deviation (SD) and analyzed using one-way ANOVA test. Subsequently, Dunnett's multiple comparison test were performed for statistical analysis. $\mathrm{p}<0.001$ was considered as statistically significant.

\section{Results}

Amphiphilic $\alpha$-helical structure of $\alpha$ AL14. The sequence of the novel model peptide we synthesized is AAWKLLKALAKAAL. It is composed of abundant hydrophobic and basic amino acids without disulfide bonds. According to some research $(19,20)$, peptides including these features tend to be cationic linear amphiphilic peptides. Basic linear peptides take an amphiphilic $\alpha$-helical structure and their amphiphilicity presents distinct biological activities (21-23). In light of these facts, it is predicted that the synthesized peptide adopts an amphiphilic $\alpha$-helical conformation because of its amino acid arrangement. According to helical wheel representation, all hydrophobic amino acid residues, A1, A2, L5, L6, A8, L9, A10, A12, A13, and L14 were located on one side, whereas hydrophilic amino acid residues, K4, K7, and K11, were located on the other side of the helix (Fig. 1). Therefore, we suggest that this peptide can be classified into the basic linear $\alpha$-helical peptides and we named it as $\alpha$ AL14 based on the number of amino acids in this peptide and its $\alpha$-helical property.

Anti-proliferative effects of $\alpha A L 14$ on HUVECs. As angiogenesis is intimately associated with endothelial cell proliferation, and most angiogenesis inhibitors affect 


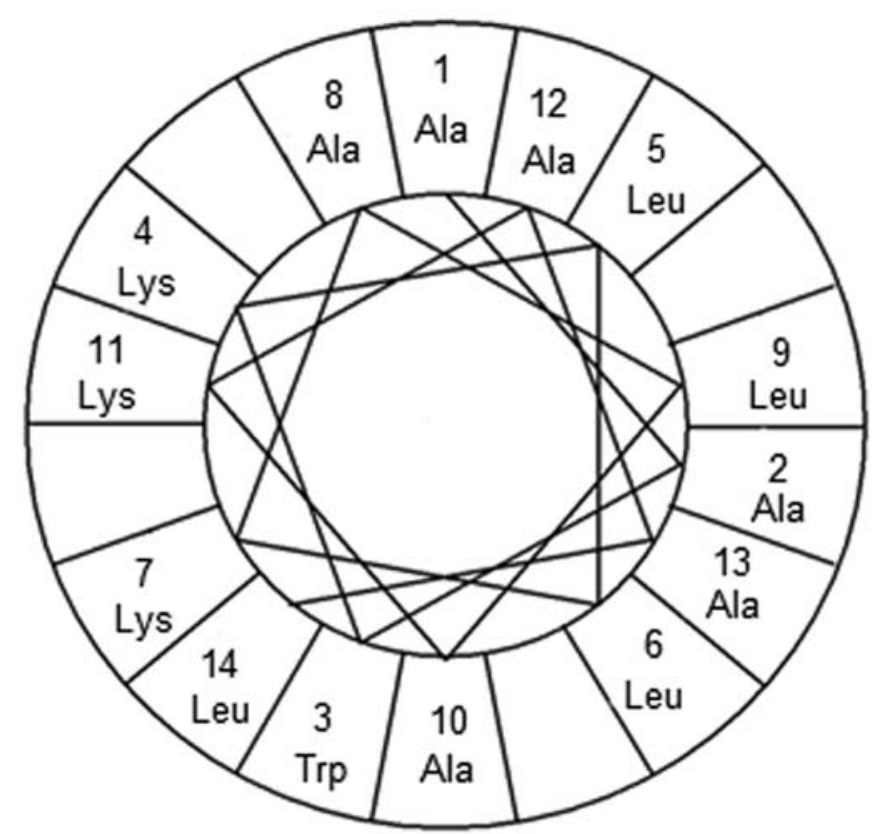

Figure 1. Predicted amphiphilic $\alpha$-helical structure of $\alpha$ AL14. In this perpendicular view of helix, the hydrophilic three Lys residues are located on one side and the hydrophobic Ala and Leu residues on the other side of the helix. endothelial cell proliferation, we investigated whether $\alpha$ AL14 can inhibit growth of endothelial cells. HUVECs, HEK-293 cells and HaCat cells were treated with $\alpha$ AL14 for $24 \mathrm{~h}$. In HUVECs, $\alpha$ AL14 did not exert an inhibitory effect on cell proliferation at $\leq 25 \mu \mathrm{M}$ but cell proliferation was decreased with a statistical significance when HUVECs was incubated with $>30 \mu \mathrm{M}$ of $\alpha \mathrm{AL} 14$ (Fig. 2A). In contrast, HEK-293 cells and HaCat cells were not affected by $\alpha$ AL14 treatment (Fig. 2A). Moreover, in order to identify whether $\alpha$ AL14 can trigger apoptosis in HUVECs, a marker of early apoptosis, phosphatidylserine presentation, was detected staining with Annexin V. As shown in Fig. 2B, Annexin V-positive cells were observed when HUVECs were treated with $>25 \mu \mathrm{M}$ of $\alpha$ AL14 for $24 \mathrm{~h}$ (Fig. 2B). Therefore, our data suggest that although HUVECs are more sensitive to $\alpha \mathrm{AL} 14$ than the other two cell lines, $\alpha$ AL14 tends to show anti-proliferative effect at high concentrations. Therefore, based on this result, we used concentrations $\leq 20 \mu \mathrm{M}$ of $\alpha \mathrm{AL} 14$ for further studies to identify biological activities of $\alpha$ AL14 excluding any inhibitory effects on cell proliferation or cell survival in HUVECs.

A localization of $\alpha A L 14$ in HUVECs. As $\alpha$ AL14 presented hydrophobic property, we expected that this peptide penetrates
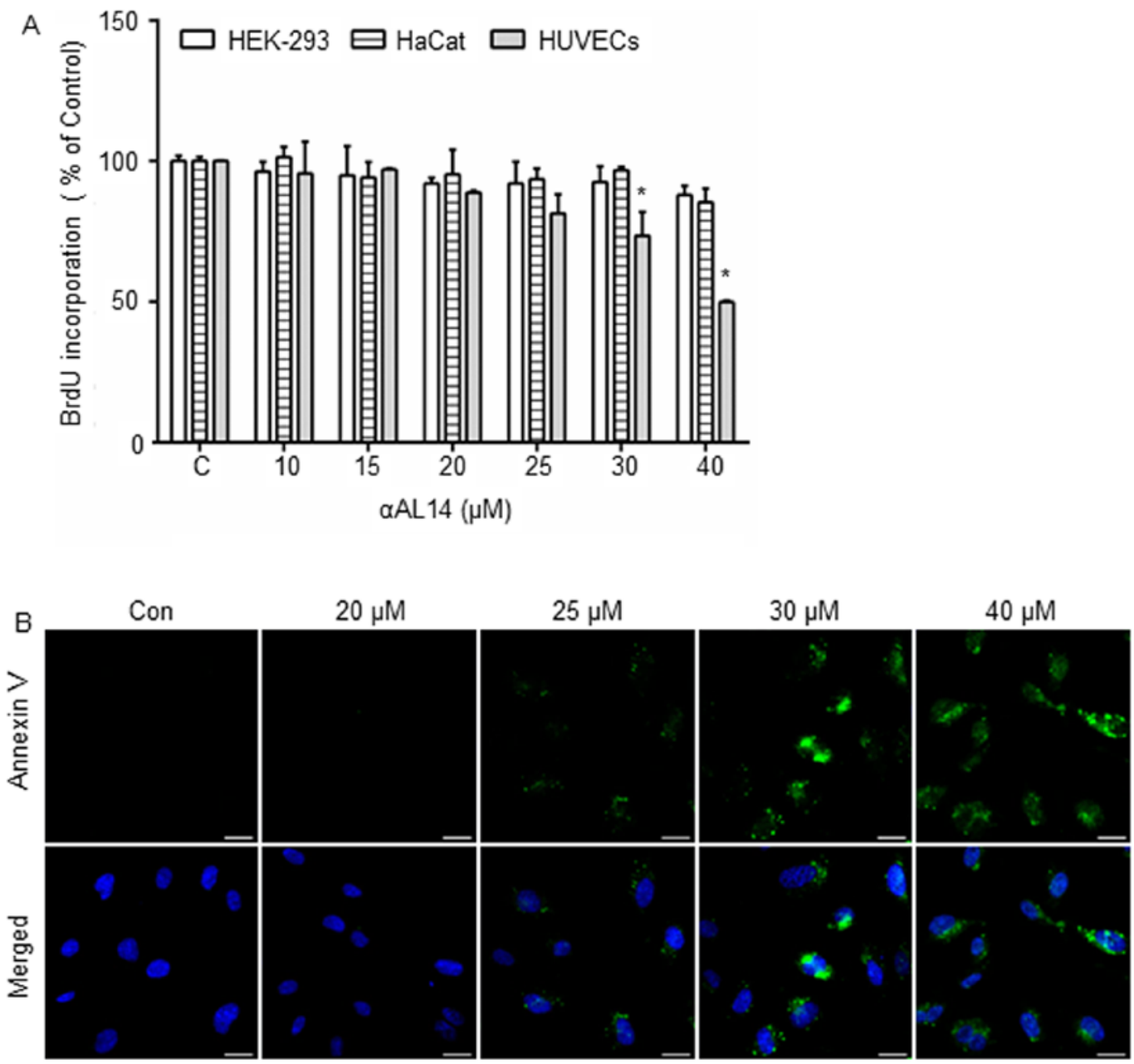

Figure 2. Effects of $\alpha$ AL14 on cell proliferation in HUVECs. (A) $\alpha$ AL14 inhibited cell viability in a dose-dependent manner. HUVECs were treated with various concentrations of $\alpha \mathrm{AL} 14$ for $24 \mathrm{~h}$ and then BrdU was added for the examination of cell viability compared to control. Each column shows the mean $\pm \mathrm{SD}(\mathrm{n}=3),{ }^{*} \mathrm{p}<0.001$. (B) $\alpha \mathrm{AL} 14$ induced early stage of apoptosis in HUVECs. The cells were incubated with indicated concentration of $\alpha \mathrm{AL} 14$ for $24 \mathrm{~h}$ and then stained with FITC-Annexin V solution to detect cells in early stage of apoptosis (green, Annexin V-positive cells; blue, nuleus; scale bar, $20 \mu$ m). 

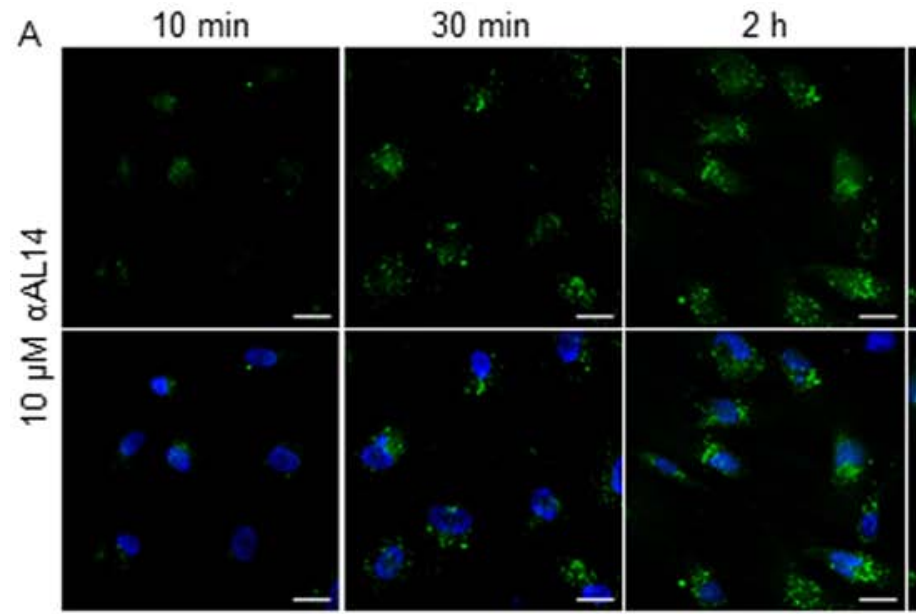

$4 \mathrm{~h}$

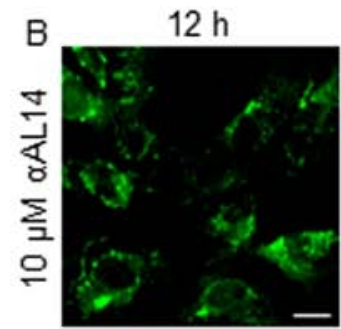

$14 \mathrm{~h}$

$18 \mathrm{~h}$
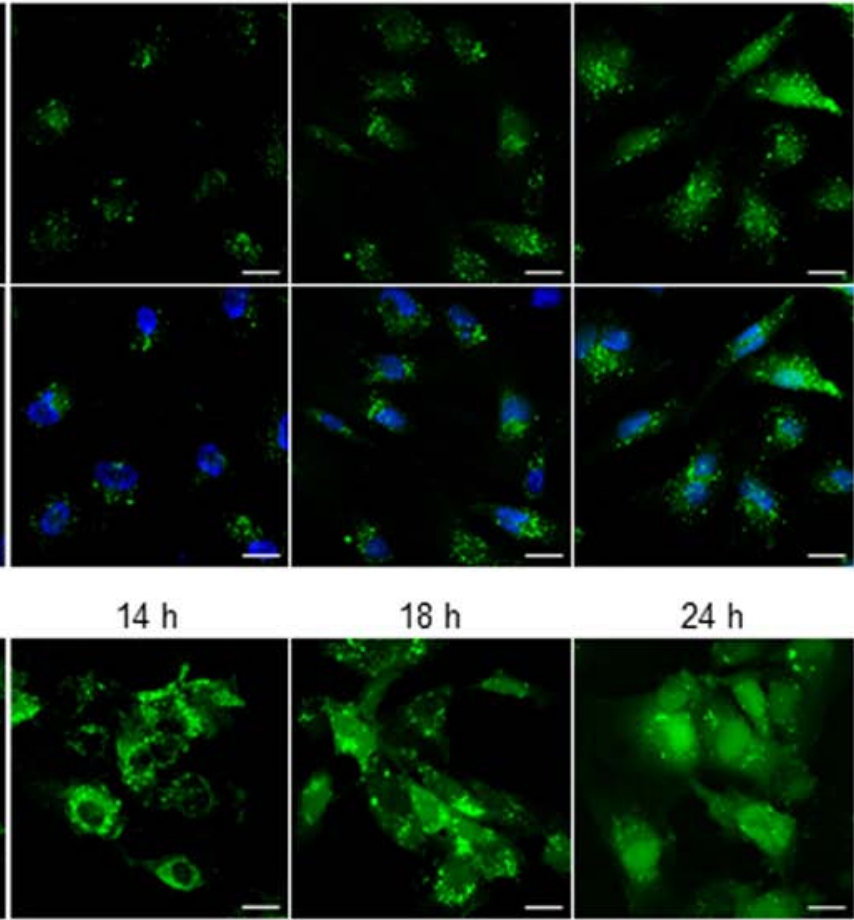

$24 \mathrm{~h}$
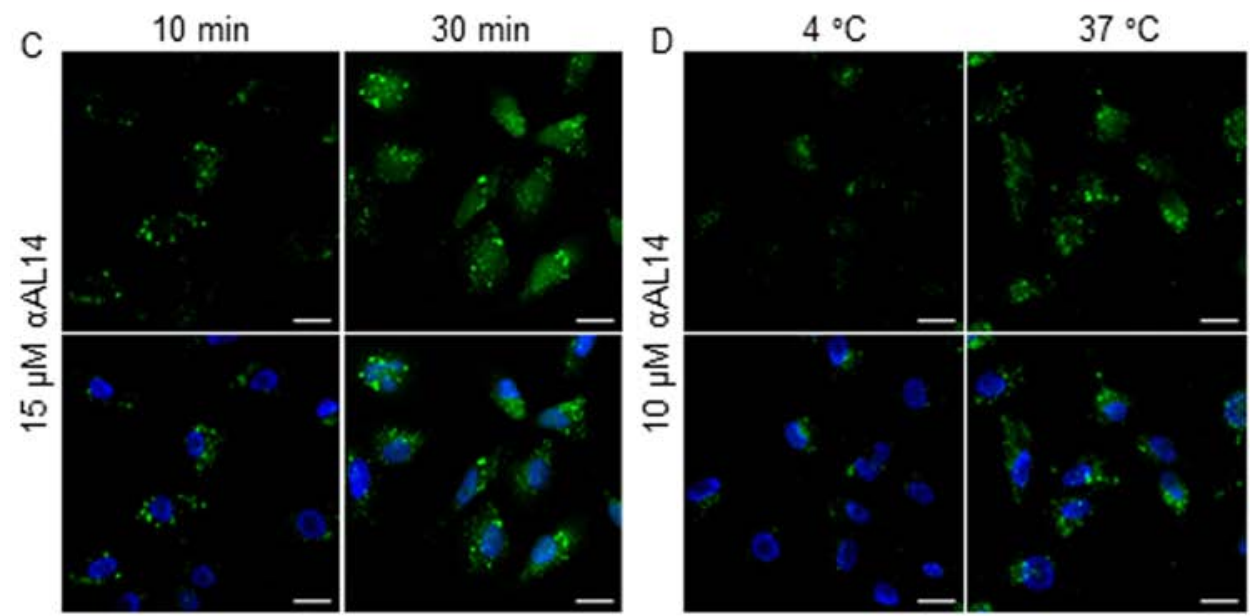

Figure 3. Entry of $\alpha$ AL14 into HUVECs. (A and B) Localization of $\alpha$ AL14 in HUVECs was observed by incubation time. HUVECs were incubated with $10 \mu \mathrm{M}$ of FITC-tagged $\alpha \mathrm{AL} 14$ at $37^{\circ} \mathrm{C}$ for $10 \mathrm{~min}$ to $24 \mathrm{~h}$. (C) Concentration-dependent entry of $\alpha \mathrm{AL} 14$ was detected. HUVECs were treated with $15 \mu \mathrm{M}$ of FITC-tagged $\alpha \mathrm{AL} 14$ at $37^{\circ} \mathrm{C}$ for 10 or $30 \mathrm{~min}$. (D) Temperature-dependent entry of $\alpha \mathrm{AL} 14$ was detected. HUVECs were treated with $10 \mu \mathrm{M}$ of FITC-tagged $\alpha \mathrm{AL} 14$ at 4 or $37^{\circ} \mathrm{C}$ for $2 \mathrm{~h}$ (green, peptide; blue, nucleus; scale bar, $20 \mu \mathrm{m}$ ).

preferentially into the cytoplasm. To prove our hypothesis, we treated HUVECs with FITC-tagged $\alpha \mathrm{AL} 14$ for the indicated time period. Even though HUVECs were treated with $\alpha \mathrm{AL} 14$ for a relatively short time, $\alpha$ AL14 rapidly internalized cytoplasm within 10 min and its FITC signal gradually increased (Fig. 3A). $\alpha$ AL14 was distributed throughout the cytoplasm and translocated into the nucleus when cells were treated for comparative long time (Fig. 3B). Accumulation of internalized $\alpha$ AL14 was increased in a dose- and temperature-dependent manner (Fig. 3C and D). However, no interactions between $\alpha \mathrm{AL} 14$ and cell membrane were detected in HUVECs.

Inhibitory effects of $\alpha A L 14$ in tube formation of HUVECs. Effects of $\alpha \mathrm{AL} 14$ on tubular morphogenesis of HUVECs were examined because several essential multiple steps including endothelial cell adhesion, invasion and migration are involved in tube formation (24). Incomplete discontinuous tubule structures were present in $\alpha$ AL14-treated HUVECs. It indicates that the formation of tubule structures was disturbed by $\alpha$ AL14 treatment (Fig. 4A). Consistent with this result, in quantitative analysis, total tube length decreased more than half degree in $20 \mu \mathrm{M} \alpha \mathrm{AL} 14$-treated cells compared to control (Fig. 4B). Taken together, the results indicate that $\alpha \mathrm{AL} 14$ is able to inhibit tubule formation on HUVECs at concentrations $>15 \mu \mathrm{M}$.

Effects of $\alpha A L 14$ on endothelial cell adhesion, migration and invasion in HUVECs. In order to identify which steps of angiogenesis can be regulated by $\alpha$ AL14 treatment, effects of $\alpha \mathrm{AL} 14$ on endothelial cell adhesion, migration and cell invasion were evaluated. First, inhibitory effects of 
A

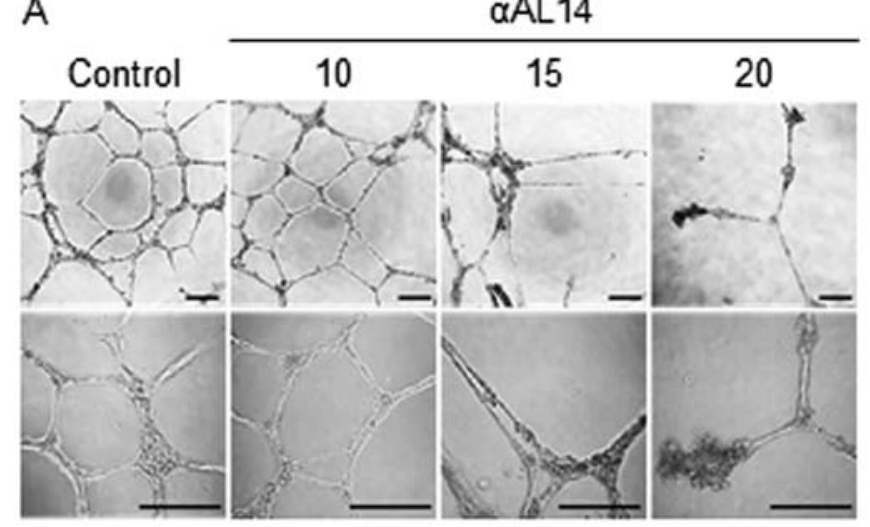

B

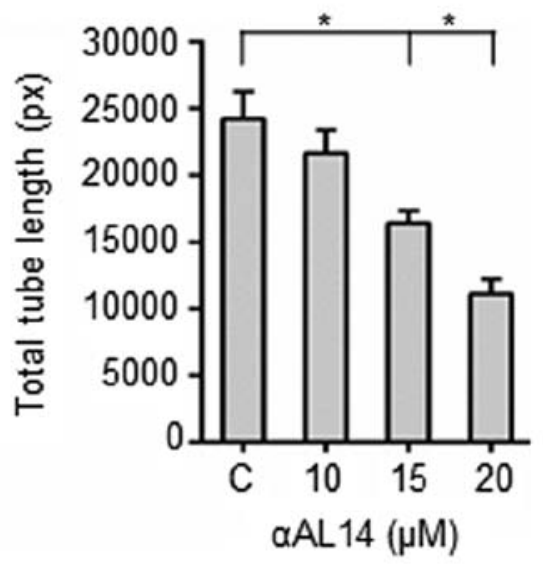

Figure 4. Effects of $\alpha$ AL14 on tube formation in HUVECs. (A) $\alpha$ AL14 decreased tubule structures. HUVECs were incubated with indicated concentration of $\alpha$ AL14 for $18 \mathrm{~h}$ on Matrigel (scale bar, $20 \mu \mathrm{m}$ ) (B) $\alpha$ AL14 decreased total tube length. Total tube length in each group was quantified. Each value represents mean $\pm \operatorname{SD}(\mathrm{n}=3),{ }^{*} \mathrm{p}<0.001$.
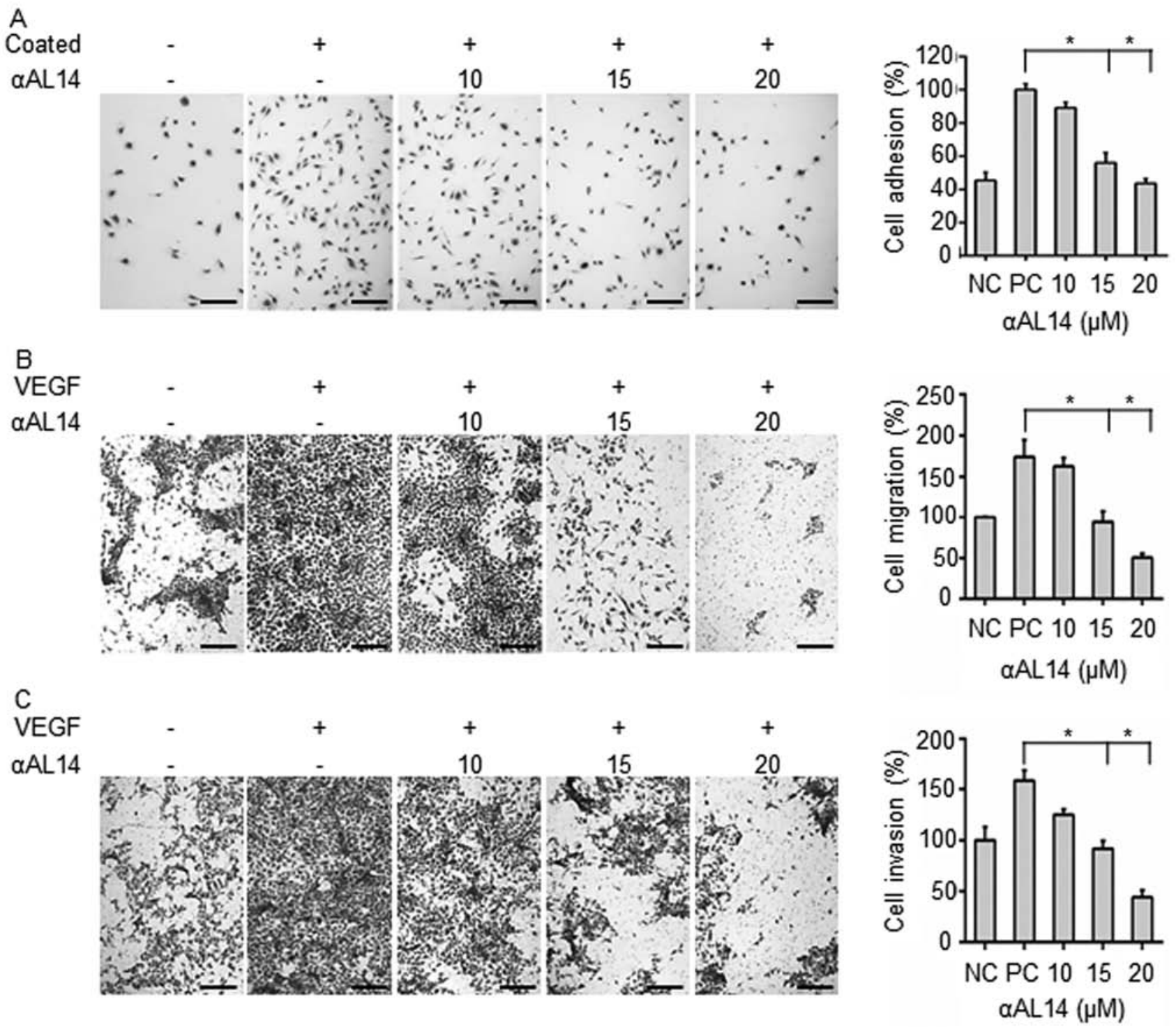

Figure 5. Effects of $\alpha$ AL14 on endothelial cell adhesion, migration and invasion. (A) $\alpha$ AL14 reduced adhesive ability in HUVECs. The cells were incubated with $\alpha$ AL14 for $2 \mathrm{~h}$ at $50 \mu \mathrm{g} / \mathrm{ml}$ in Matrigel-coated well. The cells were observed using an inverted microscope (scale bar, $250 \mu \mathrm{m}$, left panel). Relative endothelial cell adhesion ability was quantified. Adhesive ability was decreased in a dose-dependent manner compared to PC (NC, BSA-coated control; PC, Matrigel-coated control without peptide treatment). The data indicate the mean \pm SD ( $n=3$ ), " $p<0.001$ (right panel). (B and C) VEGF-induced endothelial cell migration and invasion were decreased by $\alpha$ AL14 treatment. HUVECs were incubated with various concentrations of $\alpha$ AL14 for $24 \mathrm{~h}$. VEGF (20 ng/ml) was used as chemoattractant. Images were taken by an inverted microscope (scale bar, $250 \mu \mathrm{m}$, left panel). Values are mean $\pm \mathrm{SD}(\mathrm{n}=3)$, ${ }^{\mathrm{p}}<0.001$ (right panel). 

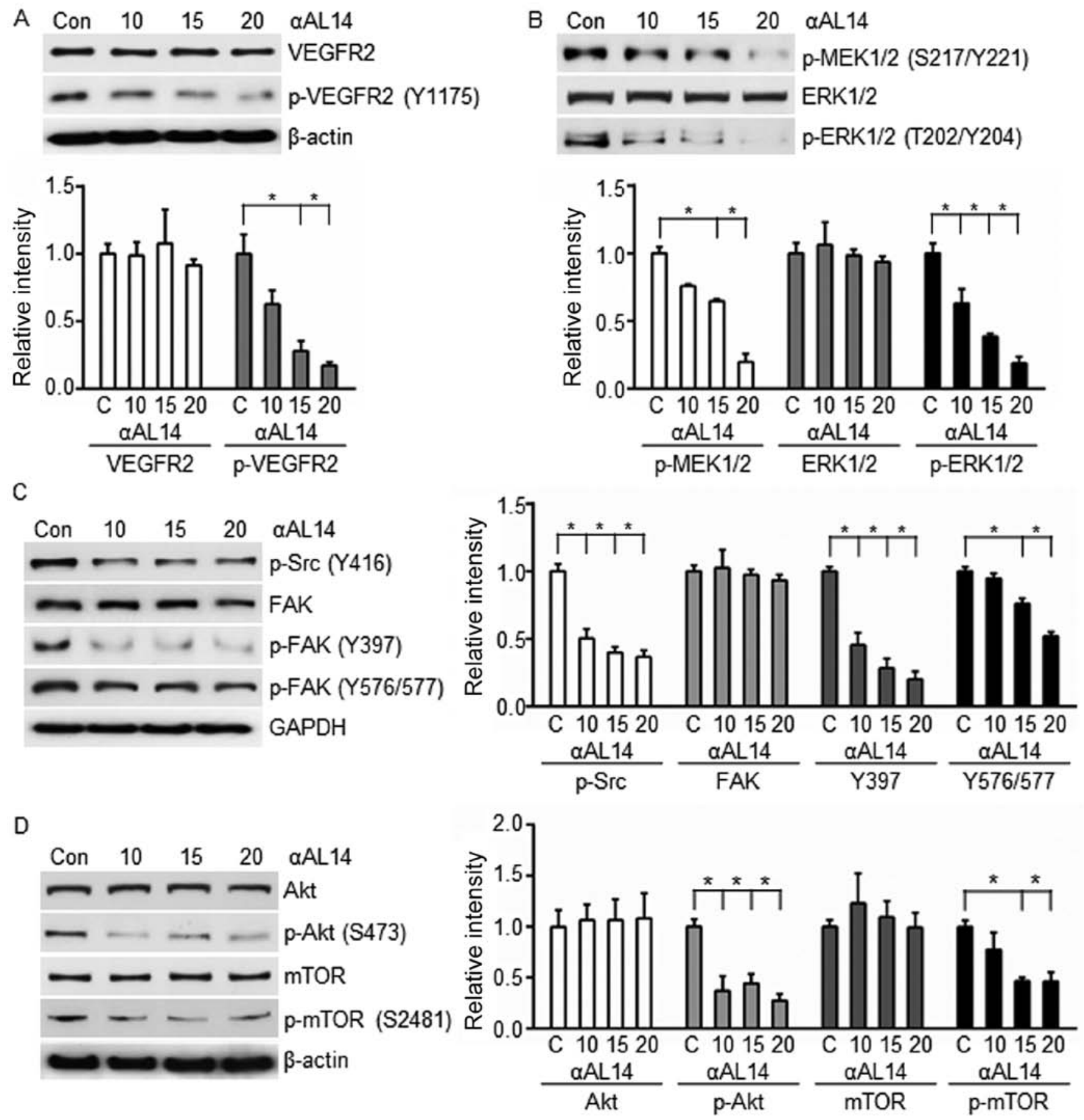

Figure 6. Effects of $\alpha$ AL14 on VEGFR2 activity and VEGFR2-mediated downstream HUVECs. HUVECs were treated with $\alpha$ AL14 for 30 min. Expression level of VEGFR2, phospho-VEGFR2 and many different components involved in VEGFR2-mediated signaling was detected using western blot analysis. Expression level of each protein was quantified. Each column represents the mean $\pm \mathrm{SD}(\mathrm{n}=3)$, ${ }^{*} \mathrm{p}<0.001$. $\alpha \mathrm{AL} 14$ decreased phosphorylated form of VEGFR2, but not total form of VEGFR2 (A). $\alpha$ AL14 inhibited the activation of VEGFR2-mediated downstream signaling. The activation of MEK and EKR (B), c-Src and FAK (C), AKT and mTOR (D) was decreased by $\alpha$ AL14 treatment.

$\alpha$ AL14 on endothelial cell adhesive ability were investigated. Adherent cells were decreased as much as negative control in $20 \mu \mathrm{M}$ of $\alpha$ AL14-treated HUVECs (Fig. 5A). In Transwell migration assay, $\alpha \mathrm{AL} 14$ significantly decreased VEGFstimulated HUVEC migration (Fig. 5B). $\alpha$ AL14 (15 $\mu \mathrm{M})$ reduced VEGF-stimulated cell migration about half degree compared to positive control in HUVECs. Following this, in Transwell invasion assay, aAL14 remarkably inhibited VEGF-stimulated HUVEC invasion compared to positive control (Fig. 5C). Therefore, the results suggest that $\alpha$ AL14 can inhibit multiple biological processes including cell adhesion, migration and invasion in endothelial cells during angiogenesis.

Effects of aAL14 on VEGFR2-mediated signaling in HUVECs. VEGF receptor 2 is a major receptor for regulating angiogenesis, which activates various downstream signaling pathways (7). In order to identify aAL14-induced antiangiogenic effects on VEGFR2-mediated signaling pathways, protein expression level of VEGFR2 was investigated. As a 
A

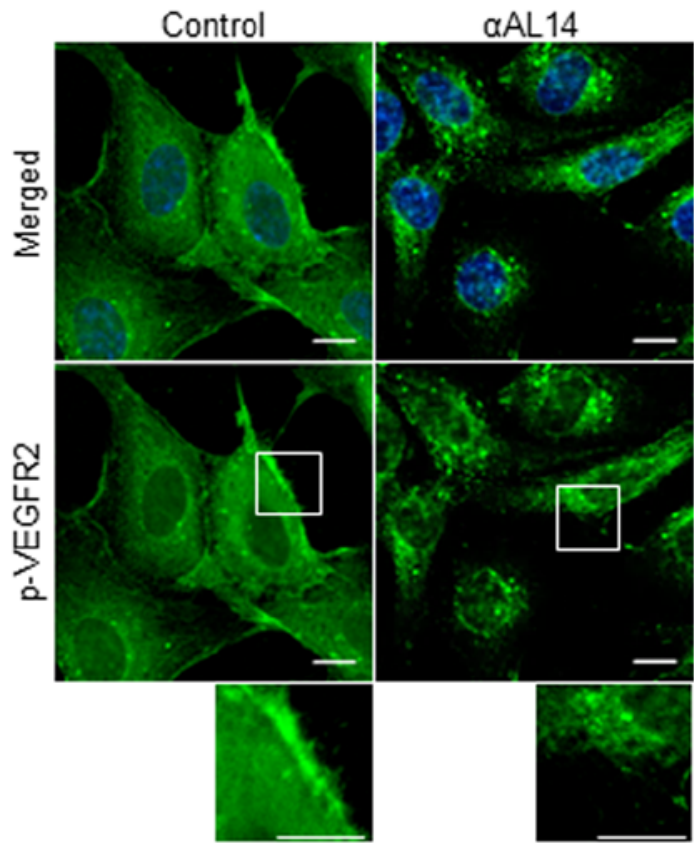

C

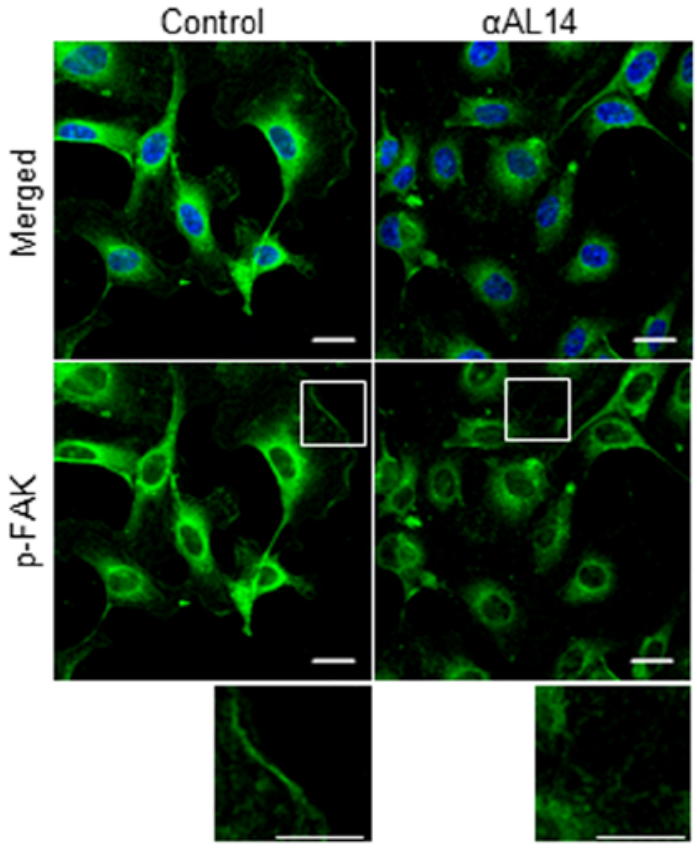

B

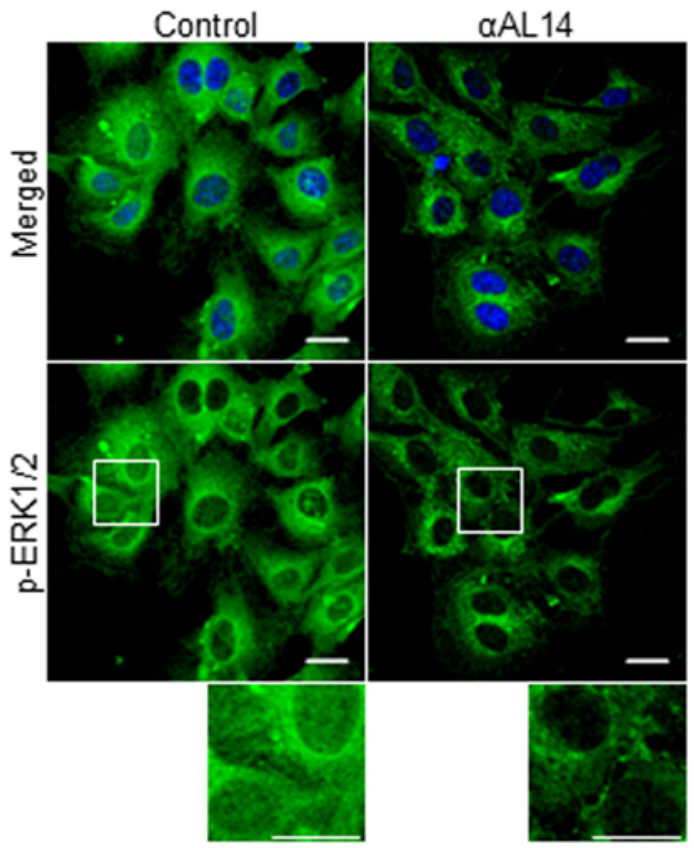

D

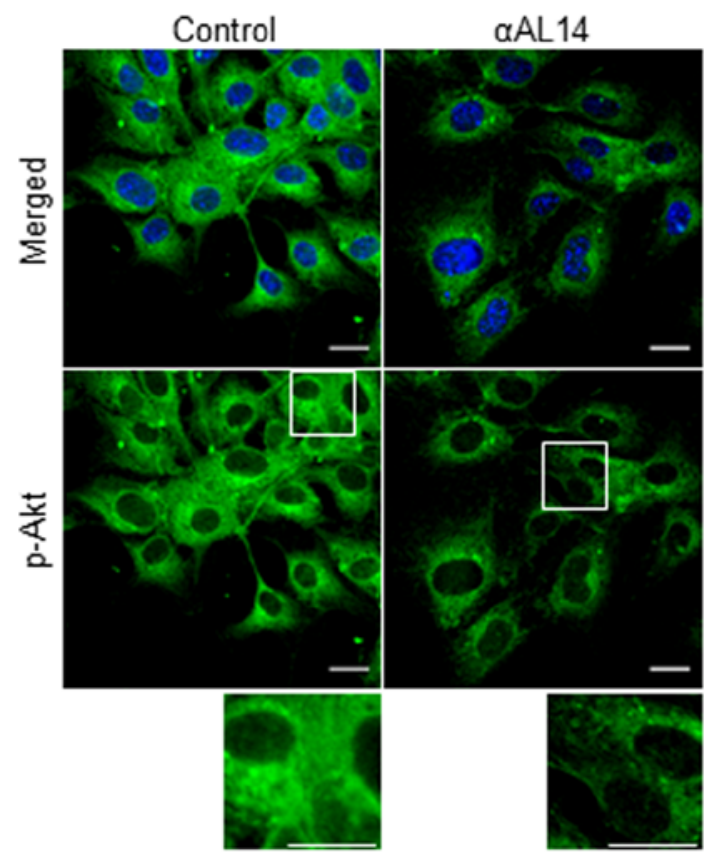

Figure 7. Effects of $\alpha$ AL14 on distribution of phosphorylated VEGFR2, ERK1/2 and FAK. HUVECs were treated with $15 \mu$ M $\alpha$ AL14 for 30 min. After incubation, cells were assessed with phosphorylated VEGFR2, ERK1/2 of FAK. Images were taken by confocal microscope. (A) Distribution of phospho-VEGFR2 was changed by $\alpha$ AL14 (scale bar, $10 \mu \mathrm{m}$ ). (B) Translocation of ERK1/2 was decreased by $\alpha$ AL14 (scale bar, $20 \mu \mathrm{m}$ ). (C) FAK activity on cell membrane was decreased by $\alpha$ AL14 (scale bar, $10 \mu \mathrm{m}$ ). (D) Phosphorylated Akt was decreased in response to $\alpha$ AL14 treatment (scale bar, $20 \mu \mathrm{m}$ ).

result, $\alpha$ AL14 significantly reduced phosphorylated VEGFR2 at Tyr 1175, but did not affect total VEGFR2 protein expression (Fig. 6A). In addition, fluorescent signal of phosphorylated VEGFR2 was diminished in response to $\alpha$ AL14 treatment (Fig. 7A). Upon these results, we hypothesized that $\alpha$ AL14 is able to downregulate VEGFR2 downstream factors and we investigated expression level of VEGFR2 downstream factors including MEK1/2, ERK1/2, Src and Akt. Consistent with our hypothesis, active form of phosphorylated MEK1/2 and ERK1/2 was significantly decreased while total ERK 1/2 was not altered by $\alpha$ AL14 treatment (Fig. 6B). In addition, aAL14 inhibited activation of Src and FAK (Fig. 6C), Akt and mTOR (Fig. 6D) in a dose-dependent manner, and most of the factors we examined were affected with statistical significance at concentration of $>15 \mu \mathrm{M}$. Altered localization of phosphorylated ERK1/2, FAK and Akt verified regulatory effects of $\alpha \mathrm{AL} 14$ on these three factors (Fig. 7B-D). Taken together, our results indicate that $\alpha$ AL14 provokes its antiangiogenic activity through downregulating the activation of VEGFR2-mediated downstream signaling pathway in HUVECs.

Effects of $\alpha A L 14$ on factors for actin polymerization in HUVECs. As actin polymerization is an essential step in 
A

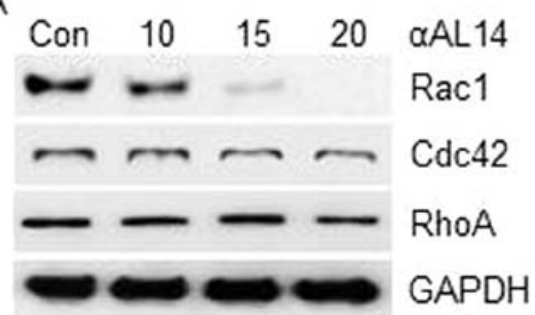

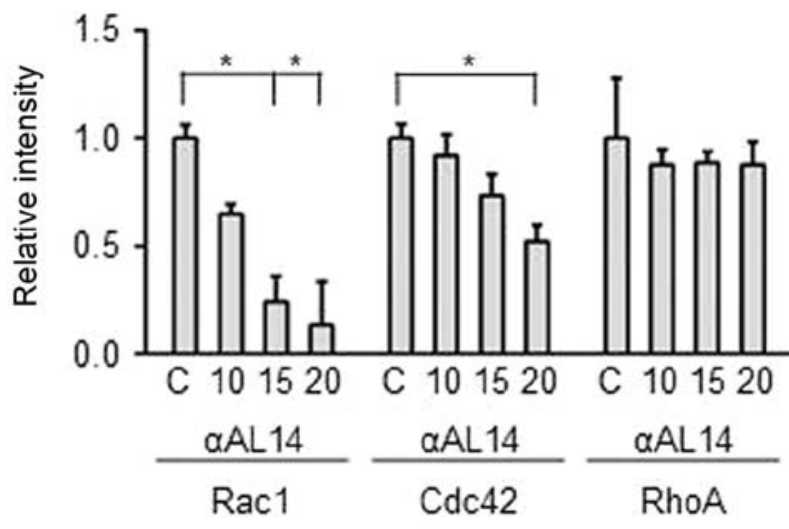

C
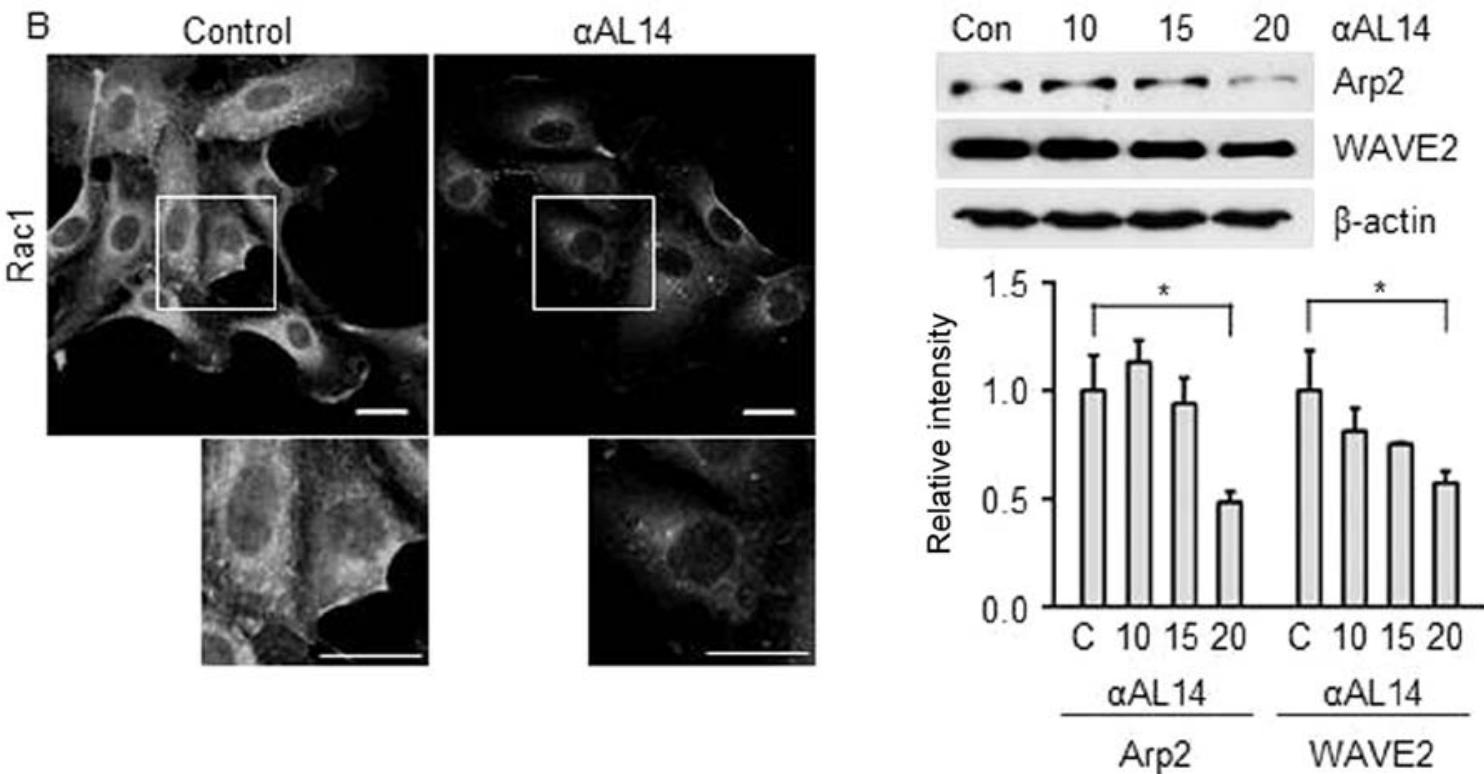

Figure 8. Effects of $\alpha$ AL14 on components related to cytoskeleton organization. (A and C) $\alpha$ AL14 suppressed expression of components related with lamellipodia formation. HUVECs were treated with $\alpha$ AL14 for 24 h. Protein expression levels of Rac1, cdc42, RhoA, Arp2/3 and WAVE2 were detected by western blot analysis. Each column represents the mean $\pm \mathrm{SD}(\mathrm{n}=3),{ }^{*} \mathrm{p}<0.001$. (B) $\alpha \mathrm{AL} 14$ changed the distribution of Rac1 in HUVECs. HUVECs were treated with $\alpha$ AL14 for $24 \mathrm{~h}$. In immunofluorescence staining, the cells were evaluated with Rac1. Images were taken by confocal microscope (scale bar, $10 \mu \mathrm{m}$ ).

endothelial cell migration, we investigated whether $\alpha$ AL14 has regulatory effect on actin polymerization-related factors Rho GTPase. Although aAL14 inhibited Rac1 and Cdc42, Rac1 was much effectively downregulated than Cdc42. In contrast, RhoA was not affected in aAL14-treated condition (Fig. 8) Thus, we hypothesized that $\alpha \mathrm{AL} 14$ is capable of regulating lamellipodia because Racl is involved in the formation of lamellipodia at the edge of cells (9). $\alpha$ AL14 relocated Racl away from cell membrane where lamellipodia formed (Fig. 8B), and suppressed expression level of Arp2/3 and WAVE2 (Fig. 8C) which are activated by Rac1 to extend lamellipodium at cell membrane (25). Taken together, our results demonstrate that $\alpha \mathrm{AL} 14$ may induce the disorganization of lamillipodium extension via impairing Rac1 signaling in HUVECs.

Effects of $\alpha A L 14$ on MMPs expression in HUVECs. Because endothelial cells secret MMPs to gain cellular motility by degrading surrounding ECM, expression level of MMP9, MMP2 and NF- $\kappa \mathrm{B}$, one of the well-known transcription factors for the transcription of MMP9 and MMP2, were examined. Expression of MMP9 and MMP2 were suppressed by $\alpha$ AL14 treatment (Fig. 9A). Phosphorylated NF- $\kappa \mathrm{B}$ were reduced in comparison with control while total form of $\mathrm{NF}-\kappa \mathrm{B}$ was not changed (Fig. 9A). As well as the decrease in protein level of MMP9 and MMP2, decrease in mRNA level was observed in response to $\alpha \mathrm{AL} 14$ treatment (Fig. 9B). Therefore, we suggest that $\alpha \mathrm{AL} 14$ can reduce the expression of MMP9 and MMP2 via suppressing the activation of $N F-\kappa B$.

\section{Discussion}

Amphipathic $\alpha$-helical model peptides have been considered as anti-bacterial agents due to their cationic net charge and amphipathic structure (26). In a recent study, Raddum et al demonstrated that seven different designed peptides based on AnxA2 exhibited anti-angiogenic effects on capillary-like network formation in co-culture system of HUVECs and smooth muscle cells. As D1-P2 peptide including $\alpha$-helical conformational structures tended to exert more significant 

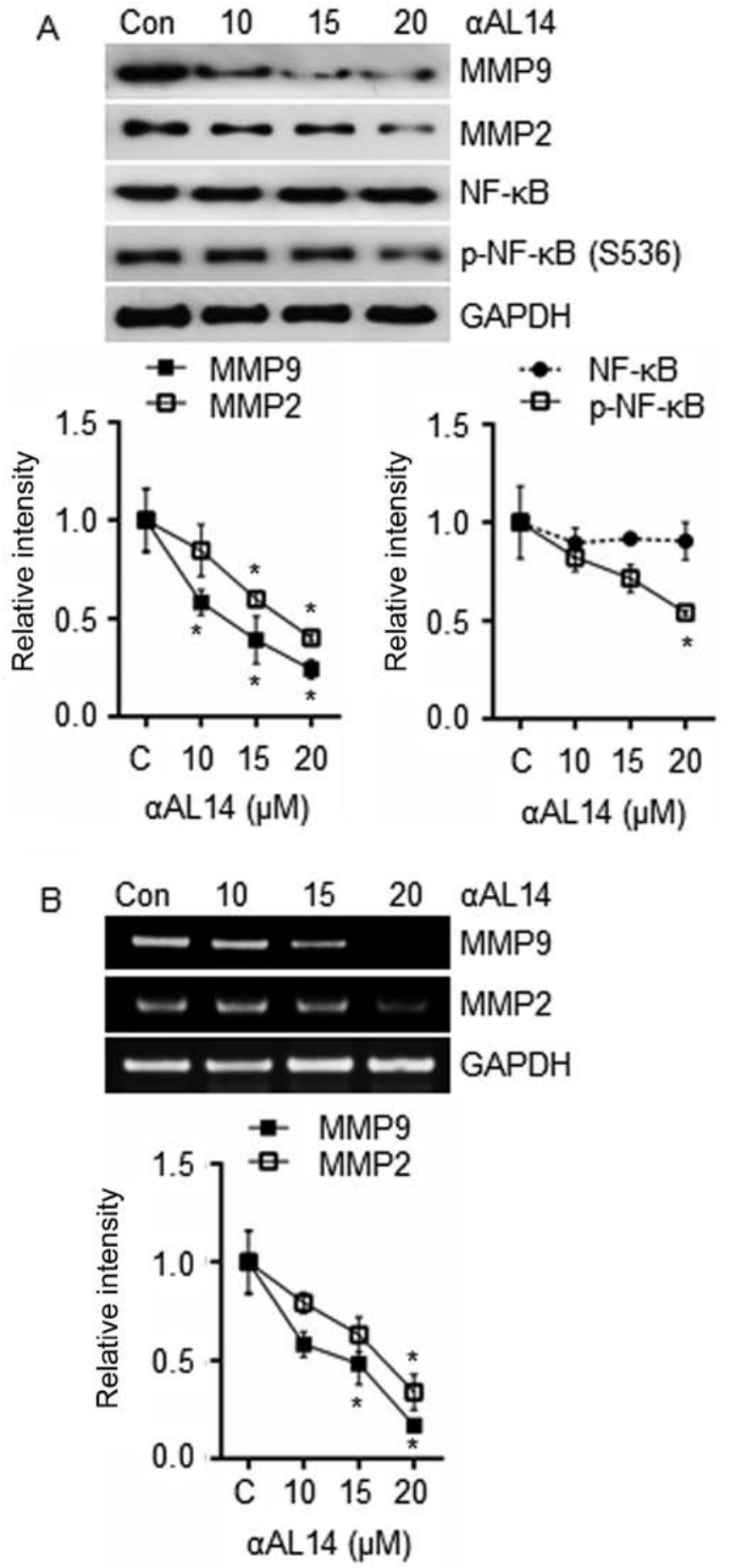

Figure 9. Effects of $\alpha$ AL14 on expression of MMP2 and MMP9. (A) $\alpha$ AL14 downregulated the expression of MMP2 and MMP9 through inhibiting NF- $\kappa \mathrm{B}$ activity. HUVECs were treated with $\alpha \mathrm{AL} 14$ for $24 \mathrm{~h}$ and protein expression levels of MMP2, MMP9, NF- $\kappa$ B and phospho-NF- $\mathrm{kB}$ were detected by western blot analysis. All statistical data represent mean \pm SD $(\mathrm{n}=3),{ }^{*} \mathrm{p}<0.001$. (B) mRNA levels of MMP2 and MMP9 were decreased by $\alpha$ AL14 treatment. HUVECs were treated with $\alpha$ AL14 for $24 \mathrm{~h}$. mRNA levels of MMP2 and MMP9 were examined by RT-PCR. Data represent mean \pm SD $(\mathrm{n}=3),{ }^{*} \mathrm{p}<0.001$.

inhibitory effect on formation of capillary-like networks rather than others (6) we expected that $\alpha$ AL14 which is assumed to contain $\alpha$-helical structure has similar effects on endothelial cells. Moreover, there have been efforts to develop endogenous peptides that can penetrate into target cells across the cell membrane because the peptides have lower toxicity without drawbacks $(3,5)$. Therefore, we focused on identifying effects of the novel model peptide $\alpha$ AL14 on angiogenic processes and its permeability in HUVECs. With negative effects of $\alpha$ AL14 on tube formation in HUVECs, $\alpha$ AL14 was able to decrease endothelial cell adhesive, migratory and invasive ability at the same range of concentrations that affected tube formation but anti-proliferative effects on HUVECs induced by apoptosis did not exist. It means that $\alpha$ AL14 is more effective in controlling endothelial cell adhesion, migration and invasion rather than its proliferation during angiogenesis.

VEGFR2 has an important role in pathological angiogenesis of which functions are allowed to become a molecular target for treating various diseases. Phosphorylation of VEGFR2 is a central event for activation of VEGF-mediated angiogenic pathways including endothelial cell proliferation and migration $(7,27)$. In our study, as phosphorylation level of VEGFR2 was decreased by aAL14 treatment, we expected that attenuated VEGFR2 can decrease its downstream factors. As we expected, aAL14 inhibited the subsequent downstream factors such as ERK, FAK, and Akt. Because phosphorylated VEGFR2 at Tyr 1175 is directly connected with an activation of MAPK/ERK and PI3K/Akt/ mTOR signaling to promote endothelial cell proliferation and migration via several downstream signaling (28-31), our data suggest that, in $\alpha$ AL14-treated HUVECs, angiogenesis can be regulated through the decrease in phosphorylation of VEGFR2.

FAK is an important component in FAK signaling relating to VEGF-induced endothelial cell migration, which can activate itself through phosphorylation at Tyr 397 (32-35). In addition, Jean et al have demonstrated that c-Src activity is required for full activation of FAK by phosphorylating Tyr $576 / 577$ in response to VEGF treatment (36). However, our data show that phosphorylation of FAK at Tyr 397 and 576/577 was diminished by $\alpha$ AL14 treatment except total form of FAK. It demonstrates that $\alpha$ AL14 can inhibit endothelial cell migration, by regulating activation of FAK in HUVECs. In addition, based on the result that the phosphorylation of FAK at 397 was much reduced compared to 576/577, it is suggested that auto-phosphorylation of FAK is affected sensitively to exposure of $\alpha \mathrm{AL} 14$ within $30 \mathrm{~min}$.

In order to identify other molecular targets of $\alpha \mathrm{AL} 14$ in connection with endothelial cell migration, expression of Rac1, Cdc42 and RhoA (members of Rho GTPAses) was evaluated because they have critical roles in actin dynamics to extend cellular protrusion (37-39). While RhoA expression was not altered by $\alpha$ AL14 treatment, the expression of Rac1 and Cdc42 was changed, and Rac1 was more affected than Cdc42. Because both Arp2 and WAVE2 cooperate with Rac1 for formation of lamellipodia (40-42) cellular level of Arp2 and WAVE2 was examined. From our data, we suggest that aAL14 may disorganize formation of lamellipodia, which is caused by the weak signal of Racl in HUVECs.

In terms of endothelial cell invasion, enzymatic families of MMPs are involved in endothelial cell invasion (12) and their transcription is regulated by certain transcription factors such as NF- $\mathrm{KB}(13,43,44)$. Therefore, our data suggest that the expression level of MMP2 and MMP9 was inhibited by 
$\alpha \mathrm{AL} 14$ through attenuating the activation of their transcription factor $\mathrm{NF}-\kappa \mathrm{B}$.

Although rapid entry of $\alpha \mathrm{AL} 14$ was observed, its internalization mechanism is not clear. However, we can suppose how $\alpha$ AL14 is transferred through the cell membrane. The improvement on internalization of $\alpha \mathrm{AL} 14$ at higher temperature indicates that its entry into cells might be mediated by endocytosis, interacting cell membrane receptors. Because several studies have described that the peptides which can easily penetrate into cells at higher temperature rather than lower temperature are entered through receptor-mediated endocytosis. Furthermore, $\alpha$-helical structure in peptides has an important role in recognition between peptides and cell receptors (45-47). Therefore, we suggest that the internalization of $\alpha$ AL14 containing $\alpha$-helical structure is connected with receptor-mediated endocytic process of VEGFR2, at least in part, in HUVECs.

In conclusion, we confirmed that the novel model peptide $\alpha$ AL14 penetrated into endothelial cells and regulated various VEGFR2-mediated signaling such as MAPK/ERK, Akt and FAK within relatively short time. $\alpha$ AL14 controlled not only Rac1 and but also Arp2/3 and WAVE2, leading to decrease in cell migration. In addition, decreased expression of MMP2 and MMP9 resulted in inhibition of cell invasion in HUVECs with $\alpha$ AL14 treatment for a relative long time. Therefore, $\alpha$ AL14 may possess two features in the regulation of angiogenesis. One is that $\alpha$ AL14 can inactivate VEGFR2-mediated signaling with preferential internalization into the cytoplasm in a short period of time. The other is maintaining its antiangiogenic effects by suppressing several factors involved in endothelial cell migration and invasion with broad distribution in cytoplasm and nucleus in HUVECs. Based on these data, we propose that $\alpha \mathrm{AL} 14$ has the potential for being developed as a new angiogenesis inhibitor.

\section{Acknowledgements}

This study was supported by a grant from the Korea Ministry of Environment (MOE) as 'Eco-innovation Program (201300030002)'.

\section{References}

1. Folkman J: Angiogenesis in cancer, vascular, rheumatoid and other disease. Nat Med 1: 27-31, 1995.

2. Carmeliet P and Jain RK: Angiogenesis in cancer and other diseases. Nature 407: 249-257, 2000.

3. Sulochana KN and Ge R: Developing antiangiogenic peptide drugs for angiogenesis-related diseases. Curr Pharm Des 13 2074-2086, 2007.

4. Nakamura $\mathrm{T}$ and Matsumoto $\mathrm{K}$ : Angiogenesis inhibitors: From laboratory to clinical application. Biochem Biophys Res Commun 333: 289-291, 2005.

5. Rosca EV, Koskimaki JE, Rivera CG, Pandey NB, Tamiz AP and Popel AS: Anti-angiogenic peptides for cancer therapeutics. Curr Pharm Biotechnol 12: 1101-1116, 2011.

6. Raddum AM, Hollås H, Shumilin IA, Henklein P, Kretsinger R, Fossen T and Vedeler A: The native structure of annexin A2 peptides in hydrophilic environment determines their antiangiogenic effects. Biochem Pharmacol 95: 1-15, 2015.

7. Olsson AK, Dimberg A, Kreuger J and Claesson-Welsh L: VEGF receptor signalling - in control of vascular function. Nat Rev Mol Cell Biol 7: 359-371, 2006.

8. Rahimi N: VEGFR-1 and VEGFR-2: Two non-identical twins with a unique physiognomy. Front Biosci 11: 818-829, 2006.

9. Ridley AJ: Life at the leading edge. Cell 145: 1012-1022, 2011.
10. Raftopoulou M and Hall A: Cell migration: Rho GTPases lead the way. Dev Biol 265: 23-32, 2004.

11. Stetler-Stevenson WG: Matrix metalloproteinases in angiogenesis: A moving target for therapeutic intervention. J Clin Invest 103: 1237-1241, 1999.

12. Rundhaug JE: Matrix metalloproteinases and angiogenesis. J Cell Mol Med 9: 267-285, 2005.

13. Adya R, Tan BK, Chen J and Randeva HS: Nuclear factor-kappaB induction by visfatin in human vascular endothelial cells: Its role in MMP-2/9 production and activation. Diabetes Care 31: 758-760, 2008

14. Nam BH, Moon JY, Park EH, Kim YO, Kim DG, Kong HJ, Kim WJ, Jee YJ, An CM, Park NG, et al: Antimicrobial activity of peptides derived from olive flounder lipopolysaccharide binding protein/bactericidal permeability-increasing protein (LBP/BPI). Mar Drugs 12: 5240-5257, 2014.

15. Ramachandran GN and Sasisekharan V: Conformation of polypeptides and proteins. Adv Protein Chem 23: 283-438, 1968.

16. Kim NH, Jung HI, Choi WS, Son BW, Seo YB, Choi JS and Kim GD: Toluhydroquinone, the secondary metabolite of marine algae symbiotic microorganism, inhibits angiogenesis in HUVECs. Biomed Pharmacother 70: 129-139, 2015.

17. Kang CW, Kim NH, Jung HA, Choi HW, Kang MJ, Choi JS and Kim GD: Desmethylanhydroicaritin isolated from Sophora flavescens, shows antitumor activities in U87MG cells via inhibiting the proliferation, migration and invasion. Environ Toxicol Pharmacol 43: 140-148, 2016.

18. Yoon JS, Kim HM, Yadunandam AK, Kim NH, Jung HA, Choi JS, Kim CY and Kim GD: Neferine isolated from Nelumbo nucifera enhances anti-cancer activities in Hep3B cells: Molecular mechanisms of cell cycle arrest, ER stress induced apoptosis and anti-angiogenic response. Phytomedicine 20: 1013-1022, 2013.

19. Bulet P, Stöcklin R and Menin L: Anti-microbial peptides: From invertebrates to vertebrates. Immunol Rev 198: 169-184, 2004.

20. Vizioli J and Salzet M: Antimicrobial peptides from animals: Focus on invertebrates. Trends Pharmacol Sci 23: 494-496, 2002.

21. Matsuzaki K: Why and how are peptide-lipid interactions utilized for self-defense? Magainins and tachyplesins as archetypes. Biochim Biophys Acta 1462: 1-10, 1999.

22. Shai Y: Mechanism of the binding, insertion and destabilization of phospholipid bilayer membranes by $\alpha$-helical antimicrobial and cell non-selective membrane-lytic peptides. Biochim Biophys Acta 1462: 55-70, 1999.

23. Zasloff M: Antimicrobial peptides of multicellular organisms. Nature 415: 389-395, 2002.

24. Arnaoutova I and Kleinman HK: In vitro angiogenesis: Endothelial cell tube formation on gelled basement membrane extract. Nat Protoc 5: 628-635, 2010.

25. Takenawa T and Miki H: WASP and WAVE family proteins: Key molecules for rapid rearrangement of cortical actin filaments and cell movement. J Cell Sci 114: 1801-1809, 2001.

26. Tossi A, Sandri L and Giangaspero A: Amphipathic, $\alpha$-helical antimicrobial peptides. Biopolymers 55: 4-30, 2000.

27. Cross MJ, Dixelius J, Matsumoto T and Claesson-Welsh L: VEGF-receptor signal transduction. Trends Biochem Sci 28: 488-494, 2003

28. Takahashi T, Yamaguchi S, Chida K and Shibuya M: A single autophosphorylation site on KDR/Flk-1 is essential for VEGF-Adependent activation of PLC-gamma and DNA synthesis in vascular endothelial cells. EMBO J 20: 2768-2778, 2001.

29. Dayanir V, Meyer RD, Lashkari K and Rahimi N: Identification of tyrosine residues in vascular endothelial growth factor receptor-2/FLK-1 involved in activation of phosphatidylinositol 3-kinase and cell proliferation. J Biol Chem 276: 17686-17692, 2001.

30. Gerber HP, McMurtrey A, Kowalski J, Yan M, Keyt BA, Dixit V and Ferrara N: Vascular endothelial growth factor regulates endothelial cell survival through the phosphatidylinositol 3'-kinase/ Akt signal transduction pathway. Requirement for Flk-1/KDR activation. J Biol Chem 273: 30336-30343, 1998.

31. Sakurai Y, Ohgimoto K, Kataoka Y, Yoshida N and Shibuya M: Essential role of Flk-1 (VEGF receptor 2) tyrosine residue 1173 in vasculogenesis in mice. Proc Natl Acad Sci USA 102: 1076-1081, 2005.

32. Qi JH and Claesson-Welsh L: VEGF-induced activation of phosphoinositide 3-kinase is dependent on focal adhesion kinase. Exp Cell Res 263: 173-182, 2001. 
33. Holmqvist K, Cross MJ, Rolny C, Hägerkvist R, Rahimi N, Matsumoto T, Claesson-Welsh L and Welsh M: The adaptor protein shb binds to tyrosine 1175 in vascular endothelial growth factor (VEGF) receptor-2 and regulates VEGF-dependent cellular migration. J Biol Chem 279: 22267-22275, 2004.

34. Braren R, Hu H, Kim YH, Beggs HE, Reichardt LF and Wang R Endothelial FAK is essential for vascular network stability, cell survival, and lamellipodial formation. J Cell Biol 172: 151-162, 2006.

35. Calalb MB, Polte TR and Hanks SK: Tyrosine phosphorylation of focal adhesion kinase at sites in the catalytic domain regulates kinase activity: A role for Src family kinases. Mol Cell Biol 15: 954-963, 1995

36. Jean C, Chen XL, Nam JO, Tancioni I, Uryu S, Lawson C, Ward KK, Walsh CT, Miller NL, Ghassemian M, et al: Inhibition of endothelial FAK activity prevents tumor metastasis by enhancing barrier function. J Cell Biol 204: 247-263, 2014.

37. Hall A: Rho GTPases and the actin cytoskeleton. Science 279: 509-514, 1998

38. Nobes CD and Hall A: Rho GTPases control polarity, protrusion, and adhesion during cell movement. J Cell Biol 144: 1235-1244, 1999.

39. Ridley AJ: Rho GTPases and cell migration. J Cell Sci 114: 2713-2722, 2001

40. Miki H, Yamaguchi H, Suetsugu S and Takenawa T: IRSp53 is an essential intermediate between Rac and WAVE in the regulation of membrane ruffling. Nature 408: 732-735, 2000.

41. Oikawa T, Yamaguchi H, Itoh T, Kato M, Ijuin T, Yamazaki D, Suetsugu $S$ and Takenawa T: PtdIns(3,4,5)P3 binding is necessary for WAVE2-induced formation of lamellipodia. Nat Cell Biol 6: 420-426, 2004.
42. Blanchoin L, Amann KJ, Higgs HN, Marchand JB, Kaiser DA and Pollard TD: Direct observation of dendritic actin filament networks nucleated by Arp2/3 complex and WASP/Scar proteins. Nature 404: 1007-1011, 2000.

43. Ho YT, Yang JS, Li TC, Lin JJ, Lin JG, Lai KC, Ma CY, Wood WG and Chung JG: Berberine suppresses in vitro migration and invasion of human SCC-4 tongue squamous cancer cells through the inhibitions of FAK, IKK, NF-kappaB, u-PA and MMP-2 and -9. Cancer Lett 279: 155-162, 2009.

44. Vayalil PK and Katiyar SK: Treatment of epigallocatechin-3-gallate inhibits matrix metalloproteinases- 2 and -9 via inhibition of activation of mitogen-activated protein kinases, c-jun and NF-kappaB in human prostate carcinoma DU-145 cells. Prostate 59: 33-42, 2004.

45. Yamada T, Fialho AM, Punj V, Bratescu L, Gupta TK and Chakrabarty AM: Internalization of bacterial redox protein azurin in mammalian cells: Entry domain and specificity. Cell Microbiol 7: 1418-1431, 2005

46. Mehta RR, Yamada T, Taylor BN, Christov K, King ML, Majumdar D, Lekmine F, Tiruppathi C, Shilkaitis A, Bratescu L, et al: A cell penetrating peptide derived from azurin inhibits angiogenesis and tumor growth by inhibiting phosphorylation of VEGFR-2, FAK and Akt. Angiogenesis 14: 355-369, 2011.

47. Bang JY, Kim EY, Kang DK, Chang S-I, Han M-H, Baek K-H and Kang I-C: Pharmacoproteomic analysis of a novel cellpermeable peptide inhibitor of tumor-induced angiogenesis. Mol Cell Proteomics 10: M110.005264, 2011. 